Studia Anglica Posnaniensia 48, 2-3, 2013

doi: 10.2478/stap-2013-0010

\title{
NECROPHELIA AND THE STRANGE CASE OF AFTERLIFE
}

\author{
MONIKA SOSNOWSKA
}

University of Łódź

\begin{abstract}
Drawing on Allan Edgar Poe's provocative statement that "The death ... of a beautiful woman is, unquestionably, the most poetic topic in the world" (1951: 369), I will focus on the pivotal role of Shakespeare's Ophelia in attesting to this assertion. Ophelia's drowning is probably the most recognizable female death depicted by Shakespeare. Dating back to Gertrude's "reported version" of the drowning, representations of Ophelia's eroticized death have occupied the minds of Western artists and writers. Their necrOphelian fantasies materialized as numerous paintings, photographs and literary texts. It seems that Ophelia's floating dead body is also at the core of postmodern thanatophiliac imagination, taking shape in the form of conventionalized representations, such as: video scenes available on YouTube, amateur photographs in bathtubs posted on photo sharing sites, reproductions and remakes of classical paintings (e.g. John Everett Millais), and contemporary art exhibitions in museums. These references will demonstrate that new cyber story - digital afterlife - is being built around the figure of Shakespearean Ophelia, unearthing the sexual attraction of the lifeless female body.
\end{abstract}

Keywords: Ophelia, popular culture, YouTube, feminist criticism, representations of the body

\section{The Ophelia phenomenon - the strange case of afterlife}

Of all "God's real creations", such as playwrights, Shakespeare made it big time. Of all Shakespeare's fictional creations, Ophelia has achieved iconic status in popular culture. The Ophelia phenomenon has flourished in the World Wide Web. Is she still a Shakespearean character? If she is no longer Shakespearean, whose Ophelia is it, anyway? She has grown into a popular eicon belonging to the Web community inasmuch as she belongs to the nonvirtual one. It needs to be highlighted here that the singular name of Ophelia has been superseded by the plural, which entails a diversity of representations, 
both real and virtual. Taking into consideration the on-line/off-line dualism, the term "strange case" of afterlife seems to be helpful and applicable here. It was Robert Louis Stevenson's idea to demonstrate how the "strangely" Jekyll/Hyde syndrome functions, while it is the metaphorical potential of double nature which inspired me to show how constructions of cyber images of Ophelia add an alter ego dimension to the existence of this Shakespearean creation. In a non-literal sense it entails doubling Ophelia's nature to such an extent that in a postmodern age, "the darker", thanatophiliac part of her image - NecrOphelia - dominates the collective consciousness of Internet users.

With regard to the four-hundred-year-old character, "to be or not to be a globally recognized icon" means "to be constantly present (and re-presented) in digital space". The number of results after entering anybody's name into the Google browser accounts for (a real or imaginary) person's popularity. Smooth proliferation of Ophelia's cultural representations in new media environment leads her to achieving indubitable fame among Internet users. Possibilities to engage with Ophelia are numerous. One can write about Ophelia in a nonacademic way, generating a personal, non-literary critical text, for example by blogging. Furthermore one can comment on an optional theatrical, cinematic, or pictorial reincarnation of that female figure, generating a non-professional review, for example by joining a forum on a website dedicated to film. In addition, one can be inspired by one of these reincarnations and even create one's own Ophelia as an image - be it a photo, a painting, or a story - and become an author of an unprofessional work, an example of this activity is publishing one's work on a photo-sharing site - Flickr being most popular - or on one's own homepage. One can, at last, become an embodiment of Ophelia by creating a video clip and posting it on a video sharing platform such as YouTube; however, this is perhaps the most challenging task.

Ophelia for an e-generation knows how to accommodate to new cultural environment in order to prolong; to lead an ever-flourishing afterlife. To be more precise, it is her image that is adapted and manipulated, being in the hands of Internet users. On the one hand, when her representations appear on different websites, she is used as a portal to play with Shakespeare's legacy, on the other - Ophelian images become portals to the selves of e-generation, reforging itself by means of toying with her iconic representations. Encountering Ophelia in pieces - limited to cyber-portions measured in bytes, generated by digital semiotic codes - and analyzing Opheliac digital afterlife, an individual may assure oneself that new interpretations of the Shakespearean dead/sleeping beauty emerge.

Before Ophelia became one of the favourite literary figures incorporated into popular culture of the Internet, she inspired different "interpreters of culture", namely, critics, artists, directors and performers. Although crystallized under 
different socio-cultural and spatio-temporal conditions, multifarious interpretations have one thing in common - specified by Kaara L. Peterson and Deanne Williams in "Introduction: The Afterlives of Ophelia":

\begin{abstract}
Ophelia is a screen on which a culture projects its preoccupations and reflects its values back onto itself. In this sense, analyzing an example of Ophelian representation at a specific historical juncture is, thus, also a neat, shorthand way to examine the workings of ideology more broadly. Reinvented for every age, Ophelia tells us more about ourselves at whatever instance we feel compelled to tell "her" story. Moreover, she has become an endlessly adaptable symbol for the universality of the feminine and, more broadly, the human psychic condition in any era, across cultures.
\end{abstract}

(Peterson and Williams 2012: 2)

Representations of Ophelia build an archive of cultural texts which may serve as a source of understanding cultural paradigms, and therefore ways of perceiving reality (e.g. Newtonian world-machine) and its inhabitants (e.g. Cartesian body/mind dualism). Ophelian renderings are indicative of both aspects: culture's existence and existing in culture. I wish to precede the proper analysis of images of dead Ophelia in Web culture and their cultural significance with a general reflection on the long history of this Shakespearean figure's afterlives.

\title{
2. Ophelia's afterlife in Western imagination
}

In his article devoted to the feminist cultural story of Ophelia, entitled "Ophelia's Sisters," Robert S. White observes that

[f]or an apparently empty vessel ("her speech is nothing"), and one who is given the
acquiescent line "I do not know, my lord," Ophelia has unexpectedly generated a
richer, more varied, and even perverse afterlife than almost any literary figure.

(White 2007: 93, italics mine)

$\mathrm{He}$ is in tandem with those scholars who have been addressing the long tradition of pathologizing, devaluating and distorting the contours of her character. Especially feminist critics have been sensitive to these matters. Some of them even end up concluding with the question about the constituent substance or quality of Shakespeare's creation, which might be the source of the open and flexible signification of Ophelia's death. Does it (the constituent substance or quality) really have to be either her mad body or her dead body from which erotic meanings spring? The insight into Ophelia's textual, visual and even acoustic afterlife persistently proves that culture's fascination with this figure focuses on her embodied quality to mesmerize, bewilder and transgress. 
As far as Ophelia's textual presence is considered, it is worth mentioning a few critical observations, which contribute to imagining her as either a dying beauty, or a dead, eroticized feminine body. Yet in both cases she has become the icon of the sexually-attractive female corpse. For centuries the brotherhood of critics contributed to what Valerie Traub (1988: 216) describes as the "fetishization of the dead, virginal Ophelia", which she simultaneously recognizes as "a strategy of containment". Traub claims that in certain plays by Shakespeare, in Hamlet among others, male characters suffer from anxieties associated with female erotic power. In order to control women's sexuality perceived in categories of chaos and disturbance, after Ophelia's drowning she is transformed into "a fully possessible object" (1988: 220), into a corpse devoid of movement, instability and mutability. Like Hamlet's and Laertes' discovery of a perfect deadly beauty, of a lifeless female body, the critics' opinions about Ophelia betray their necrophiliac imaginative inclinations. I wish to refer to a few critical opinions about this heroine.

Samuel Johnson notices the "untimely death of Ophelia, the young, the beautiful, the harmless, and the pious" (2008: 95). Samuel Coleridge remarks upon "the affecting death of Ophelia, who in the beginning lay like a little projection of land into a lake or stream covered with spray-flowers quietly reflected in the quiet waters, but at length is determined or loosened, and becomes a fairy isle, and after a brief vagrancy, sinks almost without an eddy" (2007: 129). A. C. Bradley notes that "the picture of her death, if our eyes grow dim in watching it, is still purely beautiful" (2004: 165). The above mentioned interpretations are just a segment of the traditional criticism pertaining to Ophelia, which might be tantamount to a refrain, a kind of repeated opinion about the inseparability of her bodily eroticism and her corpse being an object of beauty.

In Arthur Rimbaud's imagination, in his poem "Ophelia" (1870), Thanatos (embodied in the watery element) and Ophelia form a deadly union:

I.

Where the stars sleep in the calm black stream,

Like some great lily, pale Ophelia floats,

Very slowly floats, lying in long veils...

-Up in the woods, dogs bark, men shout.

For thousand years or more, sad white phantom, Ophelia has moved down the long black river.

A thousand years or more her sweet song

Of madness has charmed the evening air. 


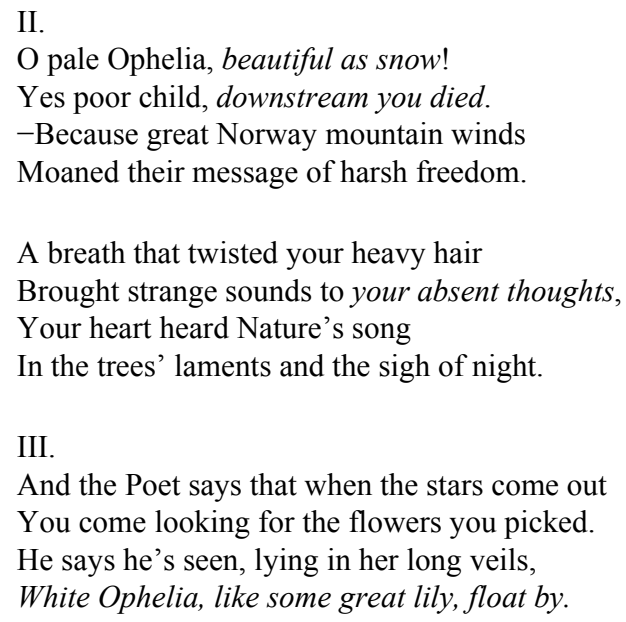

(Rimbaud 2001: 29-31, italics mine)

The images of drowned Ophelias that recur in "traditional" criticism and poetry have the connotation of the disempowered, objectified woman and beauty in death. Simultaneously, it is the interpreter's attitude towards Ophelia's body which makes her figure readable in these terms. Such renderings are firmly rooted in the textual layer, thus one of the transfigurations of Ophelia, particularly the pre-digital version, remains Shakespearean, belonging to the story depicted in Hamlet. It needs to be highlighted here that for many centuries Ophelia was invented predominantly according to men's vision. My intention is to demonstrate that Ophelian image changed through its citation into a recognition of women's subjection in postmodern culture, especially with the usage of virtual images created by amateur users of the Internet. Nowadays Ophelia's body opens up a territory for female identification in an act of self-fashioning as Ophelia. I shall return to this concept and develop it in this essay, preceding my argument with the contemporary aspects of Ophelia's role in popular culture, particularly her postmodern afterlife. Although the term "postmodern", which will frequently appear in my essay, cannot be defined in a straightforward way, I exploit John Storey studies on postmodernism and popular culture. He claims that one of the characteristics of postmodern culture is the collapse of the division between high/low culture since "there are no longer any reference points that will automatically preselect for us the good from the bad" (Storey 2005: 140). Adapting such attitude, my analysis is far from evaluating amateur works, being target of my examination, and classifying them as either culturally productive or not. 


\section{How much of Ophelia is there left in postmodern Ophelia?}

Embraced by death, the speechless and immobilized Ophelia became the target of sexual fantasies. Although the history of criticism centred around Ophelia is not the focal point of my analysis, I cannot escape engaging with a particular problem. It was a feminist perspective that changed the sexual, objectifying orientation towards the "Rose of May" (as Laertes calls his sister), offering innovative interpretations. Feminist analysts (e.g. Elaine Showalter; Gabrielle Dane; Leslie C. Dunn; Martha C. Ronk) bring her story to life - in a manner similar to systematical excavations - by bringing to light a fact that Ophelia is not, as L. L. Schücking claimed in Character Problems in Shakespeare's Plays (1992: 172), "a beautiful luxury ... superflous to the playwright's main design". In Jacquelyn Fox-Good's opinion: "Feminist critics have tried to tell Ophelia's story, or maybe to invent her story - if it is true - in Lee Edwards's (1995: 217) words, that 'Ophelia ... has no story without Hamlet"'. Feminist criticism discredits Ophelia's supplementary role in Hamlet as well as her being a supplement to Hamlet's story.

Even though most critics, Shakespeare editors and theatre directors tried to reduce her to a shadowy figure (Romańska 2005b: 488-490; 493-494), her visual presence becomes a portent of Ophelia's "fight for independence". It is also a suggestive piece of evidence to the statement that a reciprocity between beauty and death as well as between aesthetical pleasure and the feminine body exist and might be found among many visual representations of Ophelia. She became a fixation of the 19th-century painters and was immortalized on canvas by Delacroix, Millais, Waterhouse or Hughes, just to name a few. For that finde-siècle generation of artists, Ophelia became almost an obsessive pictorial motif: "Usually depicted as pale and fragile, with dishelmed hair, semi-naked or in a white dress to symbolize her purity, Ophelia's morbid beauty, enhanced by the beauty of the surrounding nature, set the standard of the nineteenth-century feminine ideal" (Romańska 2005a: 36).

In our postmodern climate, the mythological figures of Eros and Thanatos are still effectively operating on cultural basis. The popular appropriation and domestication of the inseparable couple of the god of love and the god of death has led to the mass production (understood in terms of the large-scale generation of cultural artifacts) of real or virtual materials and objects - dealing with erotic and mortal fleshiness - that circulate around the globe via technological devices. In its attempts to achieve a balance between the desire for sexual excitement and the desire to destroy, the postmodern culture of sex and death turns to (pseudo)artistic activities. These would include references to contemporary amateur and professional art works on the subject of Ophelia's corpse. The point at which death and eroticism are in equilibrium is the point of creation from which the dying or dead body is born. Ophelia, whose death is regarded as one of the most often recreated 
thanatotic moments, still remains the inspiration. Her afterlife in postmodern times differs from, for example, Ophelia's modern thanatotic reincarnations inasmuch as the cultural attitude towards "necro-eroticism", the term borrowed from Romańska's (2005b: 501) article has changed. Necro-erotic impulses and fantasies have become tamed for the purposes of popular culture, where sex and death - when embodied by women - are less anchored in cultural sphere of the taboo; they are less forbidden. From such reasoning a paradox grows. On the one hand, it entails the perpetuation of gendered stereotypes (woman as passive, beautiful and sexually attractive), while on the other - the stereotype is subverted, being manipulated by women themselves in an act of self-fashioning as unpossessible and ungraspable (but corporeal) thanatotic figures.

Popular culture of the twenty-first century is obsessed with appropriations and re-makings of Shakespeare's plays and characters, both on local and global scale, and both by professionals and amateurs. The easiest way to disseminate them is via cyberspace. Materials uploaded to Web 2.0 sites create a global poparchive, predominantly consisting of visual elements. That is why, the clones of Ophelia happen to be less and less anchored in Shakespearean Ophelia's story and more frequently they refer to common/social/widespread narrative that is also truncated, mangled and cut off, yet recognized, understood and still alive. The proliferation of Ophelia-like images within popular culture during the last twenty years has - on the one hand - rendered her figure "ophelia-less". That is to say, the famous "seductively dying creature" has been taken away from any detectable original source and displaced from the context of the play. On the other hand, her representations also remain "ophelia-ful". The latter term includes all Ophelias up to the present, accumulating pieces of this female necrofigure into one, yet paradoxically, defragmented (sometimes deformed) Ophelia. As Peterson and Williams state:

Plays and novels taking a sensationalist approach to the same topic have been written in her name (The Secret Love-Life of Ophelia); her rather more chaste and innocent girlhood story told; her French face profiled; her neoclassical, Romantic, Victorian, expressionist, surrealist, symbolist, modernist, cubist, postmodernist iterations depicted in the plastic arts; and her avatar created by online Ophelias to fit the "sim skin" of virtual reality communities. She has been analyzed by structuralism, deconstruction, poststructuralism, psychoanalysis, and new historicism. She has been revived.

(Peterson and Williams 2012: 1)

Our contemporary ocularcentric reality allows us to generate many more representations of Ophelia than in the past, when "pre-digital" technical development provided very limited means to translate the existence of this literary figure into the language of another art such as painting, or music. More importantly, there are an increasing number of people engaged in recreating and refashioning prac- 
tices, which culminate in joining the Web 2.0 community and sharing materials with other users. I would like to present a few examples of Ophelia's floating dead body, partly accounting for postmodern thanatophiliac imagination, reflecting the strange case of afterlife on the Internet.

\section{E-Ophelia is voguish, so "be in fashion and fashion yourself as Ophelia"}

Social media has intensified the need to fashion and express oneself, which might also be stimulated by competitive motives. Since one of the major functions of both traditional and new media is to make visible and promote, active consumers of popular culture wish to participate in it through an act of self-promotion. Therefore a profile on a photo- or video-sharing site also becomes a virtual place useful for self-discovery and publicity. The concept of self-fashioning, understood as conscious self-creation through many forms of shaping one's own social image (dress, gestures, voice), is discussed by Stephen Greenblatt in his book Renaissance Self-Fashioning. Greenblatt (1980: 2) suggests that "in the sixteenth century there appears to be an increased self-consciousness about the fashioning of human identity as a manipulability, artful process". If cunning and deceit are part of an image creation, then postmodern culture to which a metaphor of a wide-open and well made-up eye fits perfectly is definitely patterned on its forefather - Renaissance culture. It played a pivotal role in laying the foundations for Western visual culture. Within this culture, the gradual making/managing of one's own image is inseparable from being visually appreciated.

In addition to the limited number of former means of artistic imagining that were mainly based on the medium of painting, especially portraying or selfportraying, social constraints pertaining to gender were in force. Women could not fashion themselves to the same extent men were allowed; for example, they did not paint themselves like professional painters did. Consequently, Ophelia remained the fulfilment of the male imagination. Postmodernism introduced innovative forms of self-representation and its dissemination, unimaginable for the people of the Renaissance. With reference to creative possibilities, the cyberdimension extended the traditional dimensions of visual (auto)representation, transforming professional images of Ophelia into digital amateur user-generated representations, allowing both men and women to participate.

It should not be surprising that in the culture which feeds on permanent news (reporting) in the media, introducing new products in the market, and constant innovations (refreshing) of existing images, the self should not lose its novelty. Since we live in the age of the cult of the self, and Internet becomes the battlefield in this field of human expression, it is not an easy task to compete with other selves, understood in terms of self-representations: 


\begin{abstract}
Translated to cyberspace, users introduce themselves through alternative cues. Some may be textual, including diary-like entries or lines of poetry. But many incorporate self-portraits snapped on digital cameras or even homemade videoclips, while others include more allusive imagery, constituting a composite selfportraits.
\end{abstract}

(Ferratno 2010: 360)

A set of images, in particular photographs and films, present appropriations of Ophelia in the form of self-portraits and video clips. Google images, photosharing sites like Flickr and video-sharing systems such as YouTube offer a wide range of both, professional and non-professional representations of Ophelia. The images give a possibility to ponder on popular cultural constructions of the self, female identity and significance of women's corporeality based on the story of the body that is constantly revived in the process of iteration.

5. The art of dying in a bathtub: photographs in necrOphelian style

Although Shakespeare leaves the reader with uncertainties surrounding Ophelia's decision to die or not to die, he also leaves the reader with unlimited possibilities of re-creating this offstage tragic event. Ophelia's drowning has become an invitation to the erotically-skewed interpretation captured by the camera eye. Many contemporary participants, belonging to the popular culture of photosharing sites, decide to measure their "ophelia-ness" against their predecessors' quality to imitate her. I limited my photo search to one of the most popular photo sharing site, Flickr, which allows every Internet-user to create their own account and produce their own cultural artefacts. Photographs cannot be copied without the author's permission. This social medium enables non-professional models to stylize as Ophelia, to share some characteristics of "ophelia-ness": "mermaid-likeness," "incapability of one's own distress," and finally surrendering oneself "to muddy death".

New followers choose to radically alter the natural setting that Shakespeare prescribed in Hamlet, consisting of three constituent elements: the willow, the brook and fantastic garlands. ${ }^{1}$ They try to re-design the landscape of Ophelia's drowning, which leads to the domestication of the act of drowning, that is to say, dislocating Ophelia by "uprooting" her from the "weeping brook" into a room containing a vessel used for washing. Photos usually show Ophelia lying with her eyes closed, although some women decide to remain "alert", in a halfdying pose. As a result, postmodern Ophelia is placed in a bathtub, so that the

http://www.flickr.com/photos/gaiaart_photomaniac/4091393196/sizes/z/in/photostream/(accessed 10 June 2013). 
claustrophobic space of a bathroom replaces the open space of a streamy landscape. It is worth noting that a far-famed story about one Victorian model, who almost died while sitting for a portrait, also involves a bath. Hanna Scolnicov refers to the account in her article "Intertextuality and Realism in Three Versions of Hamlet: The Willow Speech and the Aesthetics of Cinema":

\begin{abstract}
The natural setting of stream, leaning willow, foliage and flowers, is a painting of the Hogsmill stream in Surrey. The model for Ophelia was Elizabeth Siddal, who posed in an antique embroidered gown, in a bathtub filled with water. This part of the painting was executed during winter and the water was warmed by placing candles under the tub, which, at least on one occasion, burnt out and left the model freezing and ill.
\end{abstract}

(Scolnicov 2000: 230)

Such an idea belongs to Millais, whose Pre-Raphaelite Ophelia seems to drift along the brook, with her hands out of the water. In addition, she appears to consubstantiate with the watery elements. Various features of Millais' treatment of Ophelia's death, be it her flawless garments, or "her inertia and passivism as if she had been turned into another plant in the scene" (Mesa-Villar 2004: 228), remained an inspiration for contemporary models posing for photographs in necroOphelian style. I discovered pictures described as "Lady Siddal" ${ }^{2}$ or "Lizzy, being Lizzy Siddal", 3 which make a direct reference to the Victorian model, replaced by a contemporary immature model.

The majority of photographical renderings of Ophelia - the target of my analysis - bring her closer to an ideal of a sleeping/resting dead woman, whose meeting with Thanatos might be an erotic experience, thus turning her death into a desirable event. ${ }^{4}$ In Elisabeth Bronfen's opinion:

Transforming the real body experience of death into an objectified form mitigates the violence posed by the real. Hence such a transformation can be seen as a personal or cultural strategy of self-preservation. The threat that real death poses to any sense of stability, wholeness, individual uniqueness or immortality is antidoted through representations that "exteriorize" this real by transferring it onto an image/signifier.

(Bronfen 1992: 46)

Such change pushes aside the hideousness or even monstrosity of death and locates it on the margins of popular culture. To die pretty, stylishly or even

\footnotetext{
http://www.flickr.com/photos/nokitas_black_shoes/8218087993/lightbox/ (accessed 10 June 2013).

3 http://www.flickr.com/photos/essers/2528613975/ (accessed 15 May 2013).

4 http://www.flickr.com/photos/nic_temby/4175014585/sizes/z/in/photostream/ (accessed 15 May 2013).
} 
thrillingly, becomes possible only if death "robes in" young femininity. Yet these images, either of girls, or young women, usually clothed in a dress (sometimes wearing only underwear), ${ }^{5}$ lying in their watery graves decorated with flowers, introduce uneasiness and concern. The very intimate act of washing oneself, brought to mind by the image of the bath full of water, is destroyed by the impression of a girl resting in a fixed position in a bath. A key characteristic of all these selected Ophelias is a beautiful passive female body with erotic overtones. Posed as a mortal Shakespearean heroine, models practice the art of dying inside their homes, or any other building furnished with a bath. Popular images of "mermaid-like" creatures refrain from exposing Ophelia's nudity, being in accord with the long tradition of representing her figure clothed in a dress, still, however, emanating deadly eroticism.

More attempts to express oneself characterized as Ophelia, yet not in a bathtub, are not exceptional. I discovered an outstanding collection of pictures by Merle Pace, a multimedia artist, who posted her works on a website. As she explains her fascination with the tragic figure, she incorporates autobiographical references:

\begin{abstract}
I am not sure what it is about this character, but I have been taking photographs of my friends and self-portrait of myself as "Ophelia" from Shakespeare's famous play "Hamlet" for many years now. I never have thought that she is dead though. Since I grew up the daughter of life guard parents who taught me how to swim before I could remember, I never really understood how she could drown from her heavy gowns. I was always thinking, "Just stand up in that water! Why didn't anyone teach you how to swim?! Run away! That is one messed up situation! Smack your brother out of it and run away together!". Or, I thought that she was playing "dead" by floating in the water so she could sneak away like Juliet in "Romeo and Juliet", well we all know how that turned out. Again, I was equally frustrated. ${ }^{6}$
\end{abstract}

Pace's Ophelia is romanticized and sentimentalized. The composition of four images makes an impression of a chronological disorder as if the viewer was to read the events in a reverse order. It begins with the close-up of a face belonging to a floating dead woman, surrounded by flowers, then one sees a picture, resembling a painting, where the woman is pulled into the stream, desperately trying to hold on to the ground. The picture is reminiscent of Eugene Delacroix "The Death of Ophelia" (1853), yet this time she is portrayed while she turns her back at the viewer (which I find unique), contrary to the 19th-century pictorial representation of the drowning Ophelia. The next image presents Ophelia washed up on the rocks, lying immobilized in a sleeping pose. Perhaps this

5 http://www.flickr.com/photos/noretta_imma/4409115266/sizes/z/in/photostream/ (accessed 14 Apr. 2013).

6 http://merlepacearts.com/2012/09/17/ophelia-ophelia-ophelia/. 
should be the last fragment of Pace's illustration of the final moments and the death of the tragic heroine. If one moves forward, in a clockwise direction, suddenly one encounters Ophelia decorated with red flowers, wearing a red lipstick, which add a sensuous atmosphere to the last picture. Confrontation of female sexuality with death locates Ophelia in the portentous, liminal space, where her corporeal self is forever suspended.

\section{YouTube: mass production, mass participation, mass reaction}

New media, which seem to stimulate innovative interpretations of Shakespeare and YouTube, is abundant in non-professional material, exploiting motives and figures that dwell in Shakespearean imaginary worlds. For the purposes of this article I had to narrow down my data, since my choice is to interpret postmodern versions of Ophelia's death scene. My intention is to put these representations into a broader context of our understanding of popular culture, especially Web 2.0 culture, from which YouTube phenomenon sprouted. Ophelia appearing in YouTube window might serve as an example of cyber Shakespeare and such representation, if compared with her cinematic former sisters, is not identical with them (e.g. Zeffirelli's or Branagh's creations of Ophelia). In her article "iShakespeare", Laurie Osborne states that:

The explosion of YouTube Shakespeare videos suggests that his plays provide a
useful starting place for do-it-yourself video production. From stop-action Clay-
mation to musical performances of Macbeth, Shakespearean YouTube hosts more
than rare performance recordings like the summary film of the Wooster Group
Hamlet. "Canonical" films prove useful, even recyclable, for example, in the
mini-boom of YouTube Ophelia music videos - such as Ophelia's Immortal and
Hamlet's Immortal, which set clips of Kate Winslet's performance in Branagh's
Hamlet to an array of pop songs.

(Osborne 2010: 48)

The outcome of such amateur practices is "Shakespeare made in YouTube", in other words, Shakespeare made of bits and pieces. Yet simultaneously this YouTube Shakespeare becomes signum temporis that adjusts to our hypervisual culture, along with its aesthetics of mass production of images. They become accessible almost with the speed of light to render them more tempting and competitive. This interdependence is fuelled by a simple detail and an easily forgotten fact that YouTube does not require the high costs of video production and allows mass participation due to the Internet culture being reachable globally (Strangelove 2010: 27).

Some characteristics of YouTube material are worth mentioning here: its quick dissemination, much shorter existence than typical film material, and its 
fragmentation in comparison with the duration of the material itself (understood in terms of the material's edition). YouTube window's architecture becomes another issue. Christy Desmet (2012: 548) explains that the notion of transparency does not harmonize with the YouTube window, being "a layered composite of different frames". She notes:

\begin{abstract}
The actual video is a small screen embedded in a Web page that includes other kinds of information, from the submitter's description, and metadata to viewer comments and suggested videos for further viewing. Sometimes even an advertising intervenes between the viewer and the video's virtual reality, so that the viewer of a YouTube page moves constantly from looking at and looking through the screen.
\end{abstract}

(Desmet 2012: 548)

Web 2.0 culture with its global tool - YouTube, arrange and put the (virtual) world in a new frame. New media offer totally original and hi-tech modes of mass production, mass participation, mass reaction, unfamiliar before 2006, that is to say, when YouTube originated in its embryonic stage. YouTube window or an amateur picture on Flickr are often an invitation to somebody else's world, e.g. homemade videos and self-portraits. Users of photo- and video-sharing platforms avail themselves of the medium's broadcasting tools. Finding a way of personal fulfillment in the net is not only trendy but also one of the cultivated forms of self-expression. Self-presentation in the virtual world allows for a self-discovery with the use of many a mixed images. Some of them place a female body in the limelight. Visibility in Web 2.0 enables, in the case of Ophelia - particularly female users, to fulfill their wish to be culturally meaningful. Interestingly enough, the tradition of digital self-expression does not span over three decades:

\begin{abstract}
Allowing any user to present information to others, with few intermediaries or censors, the Web permits amateurs to fashion personae and provides an audience to both receive and respond to them. Such self-fashioning began before images were incorporated into the Web; e-mail, chat rooms and MUDs introduced a performative element to digital self-presentation.
\end{abstract}

(Ferratno 2010: 361)

Our on-line identity might be invented through identification with a fictional character. This establishes Ophelia as a figure for an ideal juvenile womanhood or girlhood. Using her image or a reference to her name or story in order to reveal one's own psychological and bodily condition, an individual reaches the very existence of the self - its sensitive spiritual and corporeal part. Internet users have a possibility to perform themselves with the help of innovative digital code and recent technological tools of expression. Masses of people voluntarily and without previous training join Web 2.0 community, wishing to leave a trace in mediascape, with an intention to "materialize" in the most intangible universe. 
7. Drowning like Ophelia: amateur video scenes on YouTube

Especially the over-sexualized culture of postmodern times needs an icon living on the verge of perverse necro-eroticism and acceptable aesthetics of visual pleasure. The twenty-first century is greedy for images. They remain almost invisible for the viewers, being part of our visual landscape, yet the outcome (the image itself) is hyper-perceptible to human sight. Cases in point are ubiquitous logos in advertisements that attract us by representations - they are products of manipulation and compilation since they take part in an intertextual game of "cut, copy and paste". The viewers more or less consciously absorb these images, and as a consequence, mass consumption and mass production become interdependent. With regard to Ophelia's cyber representations, a re-creation of the amateur video scenes on YouTube is the epitome of the postmodern frenzy of: reinterpretations, remixes, reproductions, reworkings and requotations. I would suggest a category "drowning like Ophelia" since her death by immersion in water has become a recurring theme among the video scenes posted on this website. YouTubers have changed how Ophelia's death is created, circulated and consumed. I have decided to exploit exemplary scenes, picked out from the material prepared by "YouTube's global army of amateur videographers" (Strangelove 2010: 29).

Lois Potter observes that: "In fact, the cyber-media are still exploring Shakespeare's potential, with YouTube, for example, allowing anyone to perform Shakespeare at virtually no cost, and transmit the result to an invisible but potentially enormous audience" (Potter 2012: 430). The figure of Ophelia remains one of Shakespeare's literary bombshells and each time it (she) explodes, the effect gives a real shock. The cultural representations of Ophelia in YouTube culture are widely disseminated and they derive from works by visual artists and writers, from interpretations of her character in theatrical productions of Hamlet, revealing her as a nexus of the struggle for the female body's subjugation. The analysis of Web 2.0 amateur materials, especially images (of women) that women (Internet users) produced, encouraged me to put forward that Ophelia functions as a figure whose story crossed traditional media and entered the cyberspace of YouTube. This article yields insights into the most visited videosharing website while its aim is to reveal associations among gender, death and amateur techniques of performance.

The popular postmodern imagination of YouTubers contributed to many reinterpretations of Ophelia's dying scene recreated as an aestheticized pop-form. Selected films focus on the last moments of "the green girl's" (as Polonius calls his daughter) fictional life. Certain videos shorten Ophelia's story to the dramatic moment of her drowning. Others let the viewers watch as libidinal energy emanates from this female figure - an archetype of a madwoman - as she treads the path in the field or walks in the forest looking for (sexual) fulfilment. Yet it 
turns out to be destruction that she encounters. Many amateur actresses who decide to play the role of Ophelia make their bodies vehicles through which the spectacle of feminine mortality is enacted and made available to millions of other Internet users. The mood and perverse aesthetics of snuff movies is brought to mind.

Some films illustrate Ophelia's fusion with water as well as her connection with flowers. Simultaneously, the performers might deliberately cite Ophelia's lines from Hamlet, like in the short film by Mary Jo Lombardo (2010), who even explains her choice:

\begin{abstract}
Drowning in flowers while a voice over repeats lines from Shakespeare's Hamlet, this work references classical theatre, flower symbolism/imagery, the preRaphaelite painting "Ophelia" by John Millais, and funeral wreaths in an attempt to re-imagine the flower in contemporary art. $^{7}$
\end{abstract}

The authors might also intentionally avoid Shakespeare's text. Instead of it, they insert pieces of contemporary music into their works (e.g. "Honey, Honey," a song by Feist) and use, for example, "a dancing body" to tell the story of a drowning girl. ${ }^{8}$ Such is the choice of Harlore, who declares that she prepared the video clip (2009) entitled "Ophelia Drowns (Feist - Honey, Honey)" as her class project for advanced cinematography. Moreover, one of the extended versions (over 7 minutes) by Bella1951 (2011) includes a commentary by the YouTuber, explaining her fascination with Ophelia. ${ }^{9}$ This interpretation, entitled "Ophelia Drowns," is a combination of acoustic elements such as Gertrude's report (delivered by the actress) or Beethoven's "Moonlight Sonata," and of visual components, which let the performer play out the role of Ophelia in an isolated, natural (unaffected by the city life) setting. Such scenes available on YouTube allow the viewer to watch videos repeatedly, to fast forward or rewind, to reduce the volume or "louden" it, or even to change or close a YouTube window. According to postmodern cultural standards, Ophelia may die at any moment and momentarily rise from the dead, "on demand", from the viewer.

The popular responses to Ophelia's death (sometimes deliberately entitled "Ophelia's Suicide") still imitate the convention of acting out the eroticized body, uniting with Thanatos (un)consciously. The Ophelian style of dying seems to be the most desirable way of parting from this world, since the dying beauty, on the one hand, becomes the object of desire, while, on the other, she might personify death. Most death is done by elderly people, rendering death

http://www.youtube.com/watch? v=rBemxuuBJHc\&feature=related (accessed 15 May 2013). http://www.youtube.com/watch?v=ZDlgJMNhKdE\&feature=related (accessed 14 Apr. 2013). $\mathrm{http}: / /$ www.youtube.com/watch? $\mathrm{v}=$ mmq3ylfVJ3Q\&feature=related (accessed 14 Apr. 2013). 
invisible. In contrasting, the death of a young person, especially a woman, is exposed and visually longed for. From the author's description to one of the NecrOphelian videoclips entitled "The Death of Ophelia ('Dead in the Water' Ellie Goulding)," one may find out that:

\begin{abstract}
The video's concept is about a modern-day Hamlet. Ophelia is contemplating her suicide as she has flashbacks of her relationship with Hamlet. At first, she is numbed by the memories, but slowly she begins to lose her mind as she remembers her father's death, Hamlet going crazy, and Ophelia herself beginning to lose her mind. Ophelia decides to drown herself in her bathtub. ${ }^{10}$
\end{abstract}

Music becomes an important vehicle for the female performer to embody Ophelia and express grief since this almost six minutes long video clip attempts at telling a tragic story of a girl who lost her father and was left by her lover. As the girl performs the dying scene, she is shown lying in the bathtub full of water, lip-syncing to the words of "Dead in the Water" by Ellie Goulding, an English pop singer and songwriter. Dressed in black, holding a photo of herself and Hamlet, she engrosses in singing and allows the water to cover her body completely and paralyze her in a sleeping pose. Another example of a realization of the thanatopheliac phantasy to create a YouTube film and to fashion oneself as Ophelia is a short film called "Ophelia's death." Using a contemporary bathroom, the female performer drowns like Ophelia in two places at the same time. As she unites with Thanatos, the girl whispers Gertrude's report about the drowning from Hamlet and she envisions the scene in her mind's eye. Somatically immersed in water in her own bathtub, she plays out the role of Ophelia's madness and drowning in her imagination. The sophisticated montage faces the viewer with two Ophelias: one being a juvenile woman, who commits suicide by slashing her wrist in a bath (which is a common method of suicide amongst women), while the other resembles Shakespearean Ophelia, dressed in while, disheveled hair, collecting flowers, drowning in a forest stream. Ophelia's drowning happens in two realities (or perhaps in three realities - in virtual world as well): postmodern and in an unidentified past. Both Ophelias are touching, the atmosphere is thrilling, evoking intense emotions while watching a young and pretty girl die.

In Strangelove's opinion: "YouTube is home to all forms of sexual fetishes and marginal or underground sexual practices" (Strangelove 2010: 87). Amateur necro-eroticism that exploits Ophelia's theme leads to keeping cultural fantasies alive. Activity of Web 2.0 users results in prolonging her afterlife, yet more and more distant from her prototype and even gradually more deviant. A YouTube male viewer finds pleasure in watching a beautiful woman die,

10 https://www.youtube.com/watch?v=yXLv83_Mfx0 (accessed 14 Apr. 2013). 
while a non-professional actress who plays Ophelia's (last) part - through an act of self-expression - discovers unknown forms of taking pleasure in acting with their bodies, in dying like Ophelia. Female part of e-generation may discover a connection with Ophelia's corporeal image. It may serve as a mirror for themselves since it enables powerful visual self-expression. As they connect with the figure, they recognize some critical features in the young woman's body: an alienation, a suspension of an order, a break in the structure of completeness. Constructing their own identity, they turn to Ophelia and her body that is recreated and reinterpreted for their own needs in an act of self-fashioning.

What seems paradoxical about the culture of non-professional popperformers, is that many of them (ab)use immortal motives from Shakespeare, without any deeper knowledge of his literary output. In metaphorical terms, it might be stated that YouTube videos produced either at home, or in any other place, become as far from the stage or professional setting for the film as the Earth is from the Sun. Additionally, one should remember that each entering the internet culture is not innocent since it will undoubtedly leave a trail in our virtual universe. The more considerate is the trace, the better for the user.

The search for Ophelian video clips and photos proves that adolescent girls and young women find inspiration in Ophelia's bodily story. The self-fashioning they become engaged in is not equivalent with being familiar with the Shakespearean play, the source of Ophelia's afterlife in the net. It is rather an emanation of erotic power and Ophelia's iconic status that encourage female users to imitate her dying poses. Sexual attractiveness of Ophelia's young and mysterious body, on the one hand, helps female Web 2.0 community to identify with bodily mesmerizing attributes, while on the other - it enthralls male viewers. Iteration propagates the iconic image of Ophelias and propels the pursuit of visual pleasure. According to Joanne Finkelstein popculture "functions as a toolkit for shaping identity while our everyday life requires from its participants to "perform an identity' in different forms and renders this process natural" (Finkelstein 2007: 12). She accentuates that acting against this cultural obligation, individuals are "passive, blank or hesitant", or even "break social rules" (Finkelstein 2007: 12). Pre/maturing women avail themselves of an abundant repository, which creates Ophelia's representational story, discovering a current tendency to reinvent oneself and distinguish from others in rapidly changing technological times.

\section{Ophelia's death on exhibition}

Additionally, the Ophelia-type death scenes are the leitmotif of some recent gallery exhibitions. Contemporary art works on the subject of Ophelia were presented at Gallery Stratford, Canada, opened from January 17 to April 4, 
2010. "Drowning Ophelia" is the title of the exhibition, whose authors explain that it "delves into the timely and timeless allegory of Ophelia's loss of judgment and her subsequent watery demise in an exhibition of new media, video, photography, painting, and sculptural works ..." (Garnet 2010). ${ }^{11}$

Recognizing the popularity of necro-aesthetics, organizers of another exhibition appreciated the cultural role of Ophelia as a thanatotic icon. The exhibition entitled "Ophelia. Desire, Melancholy In the Death Wish," held at the Arnhem Museum of Modern Art, Holland, from February 21 to May 10, 2009 , was devoted only to the necro-figure of Ophelia, who according to the curators:

is a contemporary metaphor for the modern romantic who wrestles with conflicting feelings of reciprocal incomprehension, unrequited love, and desperate longing, and who seeks ultimate release in death. Not only does she represent the deeper layers of the feminine being, but also the indefinable desires of this side of life, to which nature ascribes symbolic meaning.

$$
\text { ("Museum") } 12
$$

As she travels in time and space, it would not be an exaggeration to state that.

\section{Ophelia will never die...}

She will always haunt cultural imagination. In my article I suggest three derivatives (two adjectives and a noun): "ophelia-less", "ophelia-ful" and "ophelianess". I treat Ophelia's oxymoronic life after death as a source from which also linguistic forms spring into being. To my mind Ophelia's inspirational status might even grow to the point that she becomes the eponym for the dead feminine beauty. Among numerous embodiments in Ophelia's afterlife, one of the most recent is being a pop icon designed and created for and by the postmodern generation seeking fulfilment of its necrOphelian fantasies: young women find satisfaction by self-fashioning in digital space as dead/sleeping beauty and male Internet users immerse in visual pleasure.

If academic research is taken into consideration, Web 2.0 Shakespeare is still a neglected aspect of Shakespeare studies. Cyber Shakespeare has just started to spin its global web. Partly, it might be explained by the fact that the history of the discussed websites, YouTube and Flickr, is limited to seven (from 2005) and eight (from 2004) years, respectively, and thus YouTube/Flickr Shakespeare is still its nascent stage. It is also noteworthy that only certain Shake-

11 http://www.gallerystratford.on.ca/exhibits/drowning-ophelia (accessed 13 Feb. 2013).

$12 \mathrm{http}: / /$ www.artdaily.org/index.asp?int_sec=11\&int_new=29209\#.UR6OF6UbevQ (accessed 13 Feb. 2013). 
spearean characters, perhaps those with a rich representational history, have inspired YouTubers/Flickr-users to adapt them to the needs of this practical and globally accessible social medium. Undoubtedly, Ophelia has acquired another dimension of cultural existence: she is now beginning to fit into her cyber body with the help of Internet performers. She has become a post/pop/necrOphelia and a prophet of her own words: "We know what we are, but know not what we may be". The future of Ophelia-the virtual bombshell will definitely be shaped by the contours of new media and the creativity of the users. The case of Ophelia afterlife remains as strange and unpredictable as Dr Jekyll's experiments with his hidden self. Perhaps an evil alter ego of Ophelia (and pop-performers) will astound and freeze the virtual as well as the real world of the future.

\section{REFERENCES}

\section{FLICKR PHOTOS}

Cardoso, Joana. 2012. Lady Siddal. http://www.flickr.com/photos/essers/2528613975/ (accessed 15 May 2013).

Essers. 2008. Lizzy, being Lizzy Siddal. http://www.flickr.com/photos/essers/2528613975/ (accessed 15 May 2013).

Létourneau-Prézeau, Valérie. 2009. Alexa la muse d'Ophélia. Sirène envoûtante. http:// www.flickr.com/photos/gaiaart_photomaniac/4091393196/sizes/z/in/photostream/ (access ed 10 June 2013).

Grasso, Eleonora. 2010. 199/365. http://www.flickr.com/photos/noretta_imma/4409115266/ sizes/z/in/photostream/ (accessed 14 Apr. 2013).

Temby, Nic. 2009. "Ophelia. http://www.flickr.com/photos/nic_temby/4175014585/sizes/ z/in/photostream/ (accessed 15 May 2013).

\section{YOUTUBE VIDEO CLIPS}

Bella1951. 2011. Ophelia drowns. http://www.youtube.com/watch?v=mmq3ylfVJ3Q\&feature= related (accessed 14 Apr. 2013).

Combs, Jordan. 2013. The death of Ophelia ('Dead in the water - Ellie Goulding) https://www.youtube.com/watch?v=ywdXE4F_XA0 (accessed 15 May 2013).

Harlore. 2009. Ophelia drowns (Feist - Honey Honey). http://www.youtube.com/watch?v= ZDlgJMNhKdE\& feature=related (accessed 14 Apr. 2013).

Lombardo, Mary Jo. 2010. Ophelia. http://www.youtube.com/watch?v=rBemxuuBJHc\&feature= related (accessed 15 May 2013).

Zung, Kristen. 2012. “Ophelia's death.” https://www.youtube.com/watch?v=yXLv83_Mfx0. (accessed 14 Apr. 2013). 


\section{SECONDARY SOURCES}

Bradley, Andrew Cecil. 2004. Shakespearean tragedy. New Delhi: Atlantic.

Bronfen, Elisabeth. 1992. Over her dead body: Death, femininity, and the aesthetic. Manchester: Manchester UP.

Coleridge, Samuel Taylor. 2007. Literary remains. Vol. 2. Teddington: Echo Library.

Desmet, Christy. 2012 Character. In Arthur F. Kinney (ed.), The Oxford handbook of Shakespeare, 536-553. Oxford: Oxford University Press.

Ferranto, Matt. 2010. Digital self-fashioning in cyberspace: The new digital self-portrait. In Jane Kromm \& Susan Benforado Bakewell (eds.), A history of visual culture: Western civilisation from the $18^{\text {th }}$ to the $21^{\text {st }}, 356-366$. Oxford \& New York: Berg.

Finkelstein, Joanne. 2007. The art of self invention: Image and identity in popular visual culture. London \& New York: I.B.Tauris.

Fox-Good, Jacqueline. 1995. Ophelia's mad songs: Music, gender, power. In David G. Allen \& Robert A. White (eds.), Subjects on the world's stage: Essays on British literature of the Middle Ages and Renaissance, 217-238. Newark: University of Delaware Press.

Garnet, Carla. 2010. Drowning Ophelia. Gallery Stratford. http://www.gallerystratford. on.ca/exhibits/drowning-ophelia (accessed 13 Feb. 2013).

Greenblatt, Stephen. 1980. Renaissance self-fashioning: From More to Shakespeare. Chicago: University of Chicago Press.

Johnson, Samuel. 2008. Preface to Shakespeare. ReadHowYouWant.com.

Mesa-Villar, María José. 2004. Musings from Ophelia's watery voyage: Images of female submission in Shakespeare's and Millais' Drowning Maiden. Sederi 14. 227-237.

Museum voor Moderne Kunst Arnhem Presents Desire, Melancholy in the Death Wish. artdaily.org. http://www.artdaily.org/index.asp?int_sec=11\&int_new=29209\#.UR6OF6UbevQ (accessed 13 Feb. 2013).

Osborne, Laurie. 2010. iShakespeare: Digital art/games, intermediality, and the future of Shakespearean film. Shakespeare Studies 38. 48-57.

Pace, Merle. 2012 Ophelia, Ophelia, Ophelia! merlepacearts.com. http://merlepacearts. com/2012/09/17/ophelia-ophelia-ophelia/ (accessed 13 Feb. 2013).

Peterson, Kara, Deanne Williams. 2012. Introduction: The afterlives of Ophelia. In Kara Peterson, Deanne Williams (eds.), The Afterlife of Ophelia, 1-9. New York: Palgrave Macmillan.

Poe, Allan Edgar. 1951. The philosophy of composition. In Thomas Ollive Mabbot (ed.), Selected poetry and prose of Edgar Allan Poe, 363-74. New York: Modern Library.

Potter, Lois. 2012. The life of William Shakespeare: A critical biography. Oxford: WileyBlackwell.

Rimbaud, Arthur. 2001. Collected poems. Trans. Martin Sorrel. Oxford: Oxford University Press.

Romańska, Magda. 2005a. NecrOphelia: Death, femininity and the making of modern aesthetics. Performance Research: A Journal of the Performing Arts 10(3). 35-53.

Romańska, Magda. 2005b. Ontology and eroticism: Two bodies of Ophelia. Women's studies: An interdisciplinary journal 34(6). 485-503.

Schücking, Levin Ludwig. 1992. Character problems in Shakespeare's plays: A guide to the better understanding of the dramatist. New York: Smith.

Scolnicov, Hanna. 2000. Intertextuality and realism in three versions of Hamlet: The willow speech and the aesthetics of cinema. In Holger Klein \& James Harner (eds.), Shakespeare Yearbook 11: Shakespeare and the visual arts, 227-237. Lewiston: Mellen.

Showalter, Elaine. 1985. Representing Ophelia: Women, madness, and the responsibilities of feminist criticism. In Patricia Parker \& Geoffrey Hartman (eds.), Shakespeare and the question of theory, 77-94. New York: Methuen. 
Storey, John. 2005. Postmodernism and popular culture. In Stuart Sim (ed.), Routledge companion to postmodernism, 133-142. London \& New York: Routledge.

Strangelove, Michael. 2010. Watching YouTube: Extraordinary videos by ordinary people. Toronto: University of Toronto Press.

Traub, Valerie. 1988. Jewels, statues, and corpses: Containment of female erotic power in Shakespeare's plays. Shakespeare Studies 20. 15-38.

White, Robert S. 2007. Ophelia's sisters. In Dympna Callaghan (ed.), The impact of feminism in English Renaissance studies, 93-113. Basingstoke: Palgrave-Macmillan. 